\title{
Las Cajas de Ahorro y las Corporaciones Locales
}

\author{
Felipe Díaz Capmany
}

\begin{abstract}
Sumario: I. NACIMIENTO DE LAS CAJAS DE AHORRO. II. EL ALCANCE LEGITIMO DE LA EXENCIÓN EN LOS AÑOS TREINTA. III. PERDURABILIDAD DEL RÉGIMEN TRADICIONAL HASTA EL TEXTO REFUNDIDO DE 1966. IV. ERROR PADECIDO POR EL TEXTO REFUNDIDO DE 1966. V. LAS SENTENCLAS DEL TRIBUNAL SUPREMO. VI. LA OCASIÓN PERDIDA. VII. EL VIRAJE INICIADO POR EL TRIBUNAL SUPREMO. VIII. PROTECCIÓN DE LA AUTONOMÍA LOCAL.
\end{abstract}

\section{NACIMIENTO DE LAS CAJAS DE AHORRO}

El Decreto de 14 de marzo de 1933 (Gaceta del día 17) aprobó el Estatuto de las Cajas Generales de Ahorro Popular. En su art. 5. reconocía el siguiente beneficio fiscal: «Disfrutarán de las mismas exenciones fiscales presentes y futuras que alcancen a las Entidades benéficas, así como de las demás prerrogativas legales que a éstas correspondan o se les confieran». Añadía en su párrafo segundo: «De consiguiente, estarán exentas de la contribución territorial e industrial y sobre las Utilidades de la riqueza mobiliaria; del impuesto de Derechos reales y del Timbre; del impuesto sobre pagos y del que grava los bienes de las personas jurídicas». Y en un tercer párrafo decía: «La exención se extenderá a los arbitrios provinciales y municipales, respecto de las operaciones anejas a las Cajas generales de Ahorro; sus anuncios y rótulos y a los bienes y fincas de su pertenencia afectos al servicio de las mismas o, en su caso, a la parte de los inmuebles que no produzcan renta por ocuparla para sus fines sociales la Institución propietaria».

La Exposición de Motivos de este Decreto de 14 de marzo de 1933 es ilustrativa. Las Cajas de Ahorro habían nacido al amparo del ordenamiento regulador de la beneficencia, como revela el art. $2 .^{\circ}$ del Real Decreto de 14 de marzo de 1899 y recuerda la Real Orden de 21 de septiembre de 1928 que aprobó los estatutos de la Confederación Española de Cajas de Ahorro Benéficas. Las Cajas de Ahorro y Montes de Piedad fueron surgiendo aisladamente, sin un amparo genérico para todas, como no fuese el general de la beneficencia. Cada una tenía, al principio, su específico reglamento y a él se sujetaba. En los repertorios legislativos se mencionan, entre otros, el reglamento de la de Madrid aprobado por Real Orden de 23 de enero de 1873, Zaragoza aprobado por Or- 
den de 28 de enero de 1873 y Barcelona aprobado por Real Decreto de 30 de noviembre de 1915. Respecto de la Caja de Madrid, su reglamento, en el art. $1 .^{\circ}$, dice que «tiene por objeto, cumpliendo la voluntad del fundador y acomodándose a las necesidades de la época, hacer préstamos en metálico sobre prendas con interés de un $6 \%$ anual, y recibir las economías de las personas laboriosas, abonándoles un $4 \%$ al añom. La dualidad, que perseverará durante largo tiempo en estas instituciones, aparece en ésta de Madrid: Monte de Piedad de una parte, dando dinero a préstamo sobre prendas, y Caja de Ahorro de otra, recibiendo depósitos de las economías modestas. Su naturaleza casi miserable aparece a lo largo de su articulado. «Todos los domingos recibirá el establecimiento en las horas senaladas la cantidad de ahorros que los imponentes depositen, admitiendo por primera imposición hasta 1.000 reales sólo y en las sucesivas desde 4 hasta 300. Las cantidades depositadas producirán un interés del $4 \%$ anual hasta la suma de 10.000 reales» (art. 18). «Podrán los imponentes retirar sus capitales siempre que quieran, sin más que el aviso de una a cinco semanas antes de la devolución» (art. 19). Su patrimonio no podía entretenerse en inmuebles: entre las funciones de la Comisión administrativa de la Caja se enunciaba en el art. $7 .^{\circ}$, sexta, la de "administrar las fincas que vinieran a ser propiedad del establecimiento; activar la venta de éstas a fin de tener siempre empleados sus fondos en el objeto de su institución'), que no era otro, como se ha visto, que dar dinero a préstamo con garantía prendaria al interés del $6 \%$, con el evidente propósito - benéfico- de evitar que las clases modestas cayesen en manos de los usureros. Al propio tiempo, mediante las Cajas de Ahorro, se facilitaba y protegía el ahorro popular.

Al cabo de poco de empezar estas iniciativas, la ley de 29 de junio de 1880 promueve la creación de instituciones de esta clase en las poblaciones más importantes. «Se procurará que se establezcan unidas unas y otras instituciones (Cajas de Ahorro y Montes de Piedad) para que recíprocamente se auxilien, mas esto no será obstáculo para la instalación independiente o aislada de un Monte o de una Caja de Ahorros, siempre que para el sostenimiento del Monte se cuente con recursos propios, y que haya medio seguro de colocar los capitales de las Cajas en las atenciones que por Estatutos o Reglamentos aprobados se establezcan» (art. 2. ${ }^{\circ}$. En el art. 3. ${ }^{\circ}$ se establecía que «las Cajas de Ahorro y Montes de Piedad establecidos y que se establezcan con autorización competente, serán considerados como instituciones de Beneficencia, y estarán bajo el protectorado del Gobierno y de sus Autoridades delegadas».

Si hasta entonces y por su naturaleza benéfica dependían del Ministerio de la Gobernación, por Real Decreto-ley de 9 de abril de 1926 quedan sometidas al Registro e Inspección del Ministerio de Trabajo, Comercie e Industria. Y bajo el impulso de ese Ministerio y de su protectorado e inspección se crea la Confederación Española de Cajas de Ahorro Benéficas. Es este Ministerio el 
que promueve el Real Decreto-ley de 21 de noviembre de 1929 que regula el régimen de ahorro popular y aprueba dos estatutos distintos: el Estatuto especial para las Cajas generales y de ahorro popular y el Estatuto especial de las entidades particulares de ahorro, capitalización y similares. En el art. 12 del primero de estos Estatutos se precisa la clase de operaciones que pueden realizar, a saber: «entregas únicas, múltiples o periódicas, voluntarias o libres, determinadas o indeterminadas, en libretas o cuentas de ahorro o imposición preferentes, reintegrables a la vista o a plazo o sujetas a pequeño plazo de avisọ, con interés o sin él, para lograr la formación de capitales, combinados o no, con factores de amortización, y todos los demás servicios y modalidades de ahorro que, no obedeciendo a fines de lucro mercantil, tengan objetivos sociales para los imponentes o para las Cajas».

En el forcejeo entre el Ministerio de la Gobernación y el Ministerio de Trabajo para hacerse con la competencia sobre estas instituciones, el Decreto de 10 de julio de 1931, suspendido por Decreto de 11 de agosto siguiente, distingue los Montes de Piedad con o sin Cajas de Ahorro que quedan bajo el protectorado del Ministerio de la Gobernación y a los que alcanzan los beneficios - se dice en el art. 2. - que las leyes conceden a las instituciones benéficas, y las Cajas de Ahorro sin Monte de Piedad, sean cualesquiera sus fines, cuyo protectorado no corresponderá al Ministerio de la Gobernación, que cesará su intervención, remitiendo los antecedentes al de Trabajo (para éstas no se establecen beneficios fiscales).

Esta tensión interministerial se trata de resolver definitivamente con el Decreto de 14 de marzo de 1933, con el que comenzábamos, que aprobó el Estatuto de las Cajas generales de ahorro popular. En la Exposición de Motivos se analizan en primer lugar «los elementos sustanciales de la actividad ejercida por las Cajas de Ahorro, las cuales, aunque investidas de carácter benéfico, atributo indispensable para ser autorizadas, presentan peculiaridades diferenciativas de las simples Fundaciones de beneficencia generales o particulares, porque no se limitan como éstas a atender a sus fines con las rentas procedentes de un capital de dotación o de subvenciones fijas que les estén asignadas, sino que mediante la administración de depósitos ajenos, cuya productividad y defensa requiere instrumentos ágiles, obtienen utilidades que les permiten acometer la ejecución de obras sociales. Entre estas últimas manifestaciones, como aspecto filial de su actuación generosa, se hallan los Montes de Piedad, los Centros de protección a la madre trabajadora, los de reeducación de inválidos, las Guarderías infantiles, las Colonias escolares y otras múltiples aplicaciones que constituyen el supremo designio de su humanitario concurso, y dañaría el concepto de Entidades económicas benéfico-sociales, que les corresponda, así como a la unidad de criterio que debe presidir la ordenación de sus movimientos, el que se desdoblase el Protectorado haciéndoles depender de 
dos jerarquías distintas». Tras estas consideraciones de la Exposición de Motivos del Decreto, se llega a la conclusión de que «las afinidades estrechas que con el Servicio de Acción Social guardan, justifica que continúen adscritas al Ministerio de Trabajo y Previsión no obstante conservar su carácter benéfico, a semejanza de lo ya establecido en orden a otras Instituciones, desgajadas del ramo de la beneficencia propiamente dicha, cuales son las Fundaciones benéfico-docentes, o independientes del Ministerio de Instrucción pública y las Entidades benéfico-docentes en el orden agrícola, pecuario o minero, trasladadas al Ministerio entonces de Fomento».

De este importante Decreto de 11 de marzo de 1933 (Gaceta del 17) que no debe confundirse con el de la misma fecha relativo al Instituto de Crédito de las Cajas de Ahorro (Gaceta del 16) conviene subrayar su art. 2..$^{\circ}$ en el que se caracteriza a las Cajas de Ahorro como «dedicadas a la administración de depósitos de ahorro de primer grado, con el propósito de invertir los productos, si los tuvieran, después de descontados los gastos generales, en constituir reservas, sanear el activo, estimular a los imponentes y realizar obras sociales o benéficas». En el art. 39 se les prohíbe expresamente «realizar operaciones de Bolsa, llamadas "dobles", las de agio de cualquier clase y otras que conculquen los principios consignados en los Estatutos; descuento de letras..., prohibiéndose asimismo el arbitraje de divisas extranjeras...»».

A los efectos que nos interesa, podemos considerar este Decreto, patrocinado por los departamentos de Presidencia, Hacienda, Gobernación y Trabajo, como el resultado final de las pugnas habidas hasta entonces entre el Ministerio de la Gobernación y el de Trabajo, terminando por conseguir éste la adscripción de las Cajas a su competencia sin perder su carácter benéfico aunque desgajadas del ramo de la beneficencia propiamente dicha. Hay, pues, sutilezas y reticencias en este punto final en el que surge la declaración, hecha en el art. $5 .^{\circ}$ del Decreto, de que «disfrutarán de las mismas exenciones fiscales presentes y futuras que alcancen a las entidades benéficas». Para determinar la medida exacta de este beneficio fiscal habrá que comenzar por ver cuáles eran los beneficios fiscales de que gozaban las entidades benéficas, porque en algún momento impreciso nació la idea difusa, vaga y errónea de que las entidades benéficas gozaban de exención tributaria total y subjetiva, lo cual nunca ha sido cierto.

\section{EL ALCANCE LEGÍTIMO DE LA EXENCIÓN EN LOS AÑOS TREINTA}

Para comprender adecuadamente el art. 5. del Estatuto de las Cajas de Ahorro de 1933 hay que situarse en aquellas fechas y tener en cuenta el sistema tributario entonces vigente en lo que podía afectar a sus actividades. Como hemos visto, 
según el art. $2 .^{\circ}$ del Estatuto, las Cajas de Ahorro estaban «dedicadas a la administración de depósitos de ahorro de primer grado, con el propósito de invertir los productos, si los tuvieran, después de descontados los gastos generales, en constituir reservas, sanear el activo, estimular a los imponentes y realizar obras sociales o benéficas». Son entidades, pues, administradoras de los depósitos dinerarios que reciben, cuyos productos los reinvierten en sus propias finalidades (para constituir reservas, sanear el activo o estimular a los imponentes); sólo se abren al exterior para realizar obras sociales o benéficas, una de cuyas partidas podía ser el Monte de Piedad. En el art. 33 del Estatuto se precisan estas operaciones de administración de sus capitales que pueden realizar: «la compra de fondos públicos nacionales, obligaciones provinciales o municipales y valores industriales admitidos al efecto, adquisición de inmuebles, concesión de préstamos y créditos hipotecarios, préstamos corporativos, préstamos con garantía personal y préstamos con garantía prendaria y sobre valores». En el art. 39 se les prohíbe expresamente «realizar operaciones de Bolsa, llamadas "dobles", las de agio de cualquier clase y otras que conculquen los principios consignados en los Estatutos; descuento de letras..., prohibiéndose asimismo el arbitraje de divisas extranjeras).

El Estatuto de 1933, en materia de tributos, nada innovó porque nada podía innovar. Se limitó a describir, en forma no afortunada, y quizá levemente tendenciosa, la realidad existente. Antes ya del Estatuto de 1933 la generalidad de las operaciones autorizadas a las Cajas de Ahorro no tributaban por la Contribución Industrial, por causa de no sujeción o de exención.

\section{A) No sujeción}

La causa determinante de la sujeción a la Contribución Industrial era el lucro. En la actualidad existe cierta confusión sobre si el lucro específico es consustancial al hecho imponible de los tributos sobre actividades económicas. En los comienzos de la Contribución industrial estaba muy claro: «sólo puede entenderse que ejerce una industria el que habitualmente se dedica a ella con ánimo de obtener lucro" (STS de 23 de noviembre de 1891 y 1 de diciembre de 1927). «La Contribución industrial, por su esencia y armonía con las disposiciones vigentes, sólo puede exigirse por el ejercicio de aquellas industrias, profesiones, artes y oficios en los cuales se obtenga lucro o granjería) (STS de 13 de marzo de 1892). «Es indudable que el espíritu del reglamento, manifiesto en las exenciones que determina, es no gravar el ejercicio de las profesiones industriales con un fin benéfico o de caridad; $y$ en este concepto, $y$ demostrado en el oportuno expediente que un médico ejerció su profesión con fines caritativos, gratis y en beneficio de los enfermos pobres, no puede decirse que en el caso exista materia susceptible de gravameny (STS de 12 de marzo de 1896). «La realización de un solo acto u operación aislada, ni las varias operaciones 
de préstamo realizadas por el demandante, porque lo han sido en condiciones que excluían todo ánimo de lucro y mediando entre ellas intervalos de tiempo lo bastante largo para acreditar que no constituían tales operaciones un modo de vivir ni su ocupación profesional» (STS de 20 de junio de 1901). Si esto pudo ser dudoso en algún momento, lo confirman las Bases de ordenación de la Contribución industrial, aprobadas por Real Decreto-ley de 11 de mayo de 1926, siete años antes del Estatuto de las Cajas, de 1933. Según la Base 3. ${ }^{a}$, «la Contribución industrial tendrá por base el volumen anual de ventas u operaciones cobradas por los sujetos a ella». De forma que quien realice operaciones descritas en los epígrafes de las tarifas pero no cobre por ellas queda al margen de la contribución. Por esta causa y no por una genérica declaración de exención que nunca existió, las entidades benéficas, esencialmente gratuitas en sus prestaciones por aquel entonces, no estaban sujetas al tributo. Partiendo de este punto, de que sin lucro no hay actividad económica gravable, pierden importancia los beneficios tributarios para las entidades benéficas, que se mueven al margen del lucro. Pero, importante, el lucro a tener en cuenta, no es el lucro general de toda una actividad, es decir, el móvil último de la entidad, puesto que por definición es inexistente en las benéficas, sino el lucro inherente a las operaciones que realizan, independientemente de que los excedentes se destinen a finalidades benéficas, altruistas o caritativas sin obtención de ganancias.

La consecuencia inmediata es que las operaciones de captación de depósitos, que en sí mismas no comportaban ningún lucro, quedaban al margen de la Contribución industrial y así lo revelaban las Tarifas que ningún epigrafe contenian describiendo esa actividad. Lo mismo ocurría con las operaciones de administración consistentes en la constitución de reservas, saneamiento del activo y estímulo a los imponentes, operaciones de por sí ajenas asimismo al lucro. Las operaciones autorizadas por el art. 33 del Estatuto en que podía materializarse la constitución de reservas tampoco eran objeto de las Tarifas de la Contribución industrial; no figuraban en ella, como siguen sin figurar en la actualidad en el Impuesto sobre Actividades Económicas, la compra de fondos públicos, obligaciones provinciales o municipales y valores industriales y la adquisición de inmuebles.

Sólo la concesión de préstamos y créditos hipotecarios, préstamos corporativos, préstamos con garantía personal y préstamos con garantía prendaria y sobre valores estaría en principio sujeta a la Contribución industrial, supuesto obviamente que tales inversiones se realizasen con percepción de intereses, pero veremos enseguida qué pasaba con estas operaciones.

En fin, las obras sociales o benéficas, en las que podían también invertir sus productos, eran esencialmente gratuitas, por lo que el requisito de lucro, indis- 
pensable para la Contribución industrial, no existía, y el tributo, por tanto, era inaplicable.

\section{B) Exención}

En las Tarifas de 1896 (Real Decreto de 28 de mayo con modificaciones posteriores), bajo el $n .^{\circ} 62$, se recoge como actividad sujeta a la Contribución industrial la de los prestamistas, «entendiéndose como tales los que con establecimiento abierto al público o en otra forma, prestan dinero con la garantía de valores del Estado, sueldos personales, alhajas, prendas, muebles u otros efectos, o por escritura pública que no sea hipotecaria, juicios llamados convenidos, pagarés y recibos». En consecuencia, las Cajas que realizasen este tipo de operaciones estaban sujetas al epígrafe de los prestamistas. Pero ocurría que los préstamos de esta clase habían sido declarados exentos en la Tabla de exenciones de las Tarifas de 1896: «quedan exentos del pago de la Contribución industrial las profesiones, industrias y oficios siguientes: 10. Cajas de Ahorros y Montes de Piedad establecidos con aprobación del gobierno cuyos capitales y acumulación de beneficios se emplean exclusivamente en préstamos sobre alhajas y otros efectos sin distribución de beneficio alguno entre los fundadores. $\mathrm{Si}$ dichos establecimientos estuviesen creados con cualquier objeto de especulación, serán considerados como Sociedades anónimas y pagarán por el concepto que les corresponday. Esta exención de las Cajas ha sido repetida luego en términos idénticos en las Tarifas de 1941 y 1950. Incluso, la misma fórmula de exención se empleó para la Contribución de Utilidades en el Real Decreto de 17 de septiembre de 1906.

Conviene, sin embargo, fijarse en esa fórmula legal de exención. Es una declaración de exención subjetiva, pero sólo para las Cajas de Ahorro y Montes de Piedad cuyos capitales y acumulación de beneficios se empleen exclusivamente en préstamos sobre alhajas y otros efectos. Al pie de la letra, sólo beneficiaría a las Cajas cuyas operaciones activas fuesen de Montes de Piedad, tal como había ya previsto el Decreto de 10 de julio de 1931, que quedó en suspenso en virtud del Decreto del 11 de agosto siguiente. Este Decreto de 10 de julio de 1931 se adaptaba con absoluta precisión a la exención tributaria vigente desde 1896. Benévolamente, podía entenderse, y al parecer así se entendió de hecho, que las Cajas que, además de inversión en Monte de Piedad, realizasen cualesquiera de las otras operaciones autorizadas por el art. 33 del Estatuto pero no gravadas por la Contribución industrial, estaban en situación tributaria análoga y podían disfrutar de la exención. Hoy, sin duda, esta interpretación no sería admisible.

Hasta aquí, lo peculiar de las Cajas. Pero éstas, además, como cualesquiera otras entidades benéficas -en el seno de la beneficencia habian naci- 
do- gozaban de una ventaja complementaria de signo tributario. En la Tabla de exenciones de 1896 se establecía: «Quedan exentos del pago de la contribución industrial las profesiones, industrias y oficios siguientes: 26. Hospitales, Casas de Beneficencia, de Socorro y demás establecimientos piadosos por las corridas de toros, novillos, bailes de máscara y otros espectáculos públicos de que sean empresarios los mismos establecimientos representados por sus patronos o Juntas encargadas de la administración; y por los talleres de zapatería, alpargatería, sastrería y cualesquiera otros que tengan dichas casas y establecimientos, cuando sólo se inviertan sus productos en los acogidos, sin venta alguna al público. Para disfrutar esta exención deberá justificarse que los productos de los espectáculos han ingresado en el establecimiento de que se trate. Igualmente disfrutarán exención las expresadas casas, hospitales y establecimientos piadosos por las reses que en sus edificios tengan para que consuman, la leche que las mismas produzcan, los enfermos y asilados, siempre que este líquido no se venda al público bajo ningún concepto». El campo de los beneficios tributarios para las entidades benéficas en la Contribución industrial empieza y termina en este enunciado, y del mismo no se infiere ninguno que pudiera ser aprovechado especialmente por las Cajas de Ahorro.

Es patente, pues, el carácter absolutamente restrictivo de las exenciones concedidas a las entidades benéficas en general y a las Cajas de Ahorro en particular. En cuanto despuntaba algún género de lucro, en alguna de sus actividades, estaban sujetas a la Contribución industrial. No quedaban lejos todavía las leyes desamortizadoras que tuvieron, en los privilegios tributarios, uno de sus detonantes. Cuando el Estatuto de 1933 declaró, en su art. 5. ${ }^{\circ}$ la exención de las Cajas, se limitó a reseñar —otra cosa no podía hacer- la situación tributaria de que disfrutaban con arreglo a la normativa vigente. Pero en lugar de remitirse a ella, se aventuró en un enunciado prolijo. Conjugando, de una parte, las actividades y operaciones que dentro del conjunto de las legalmente autorizadas realizaban en la práctica, y de otra, las normas tributarias existentes, se llegaba a la conclusión, por las causas antes indicadas de la no sujeción o de la exención generosamente entendida, que las Cajas no debían realizar ninguna aportación por el concepto de Contribución industrial, conclusión que la realidad de los hechos confirmaba. Esta situación de hecho quedó reflejada en el art. $5 .^{\circ}$ del Estatuto de 1933 en una fórmula de exención subjetiva, cuando legalmente no había tal.

Es curiosa la redacción del art. 5. ${ }^{\circ}$ del Estatuto de 1933. Considerando que, por entonces, se seguía admitiendo - como hemos visto- su condición de entidades benéficas, era aceptable el primer párrafo del artículo, consistente en la homologación a los efectos tributarios de las Cajas con las entidades benéficas. Lo que no era aceptable era el segundo párrafo que, como consecuencia concreta de aquella homologación (empieza este segundo 
párrafo con la fórmula de consiguiente), declara la exención de la Contribución industrial sin limitación alguna. La circunstancia de que las entidades benéficas no estuviesen sujetas a Contribución industrial no era por el hecho de ser benéficas, pues ningún texto legal contenía declaración alguna de este género, sino porque sus actividades, al no ser lucrativas, carecian del requisito esencial de sujeción. Las Cajas, en las operaciones no lucrativas, seguían la misma suerte que las entidades benéficas, pero no por asimilación a éstas, sino por las normas propias de la Contribución industrial. En lo que fuesen operaciones lucrativas necesitaban, como las entidades benéficas, de una declaración expresa de exención. Éste era el régimen de 1933 y no podía ser otro.

Desde 1911, la ley de Administración y Contabilidad de la Hacienda Pública ( 1 de julio de 1911) establecía en el art. 5. ${ }^{\circ}$ : «No se concederán exenciones, perdones, rebajas ni moratorias para el pago de las contribuciones 0 impuestos públicos, ni de los débitos al Tesoro, sino en los casos y en la forma que en las leyes se hubiere determinado. La exención de contribuciones o la limitación de éstas con arreglo a las Leyes, serán de la competencia exclusiva del Ministerio de Hacienday. La Tabla de exenciones de 1896 de la Contribución industrial quedó convalidada por el Real Decreto-ley de 11 de mayo de 1926, que aprobó las Bases de ordenación de dicha Contribución industrial, cuya Base 2. ${ }^{a}$ remitía, en cuanto a exenciones, «a las contenidas en la Tabla que formará parte del Reglamento». El Real Decreto de 14 de marzo de 1933 no podía, por falta de rango, exceder los límites de la Tabla de exenciones aprobadas por previsión de la ley a nivel reglamentario. Supuesto que se entendiese que lo excedía carecía de validez. La consecuencia última es que las $\mathrm{Ca}$ jas de Ahorro, en su actividad típica, no sobrepasaban la exención prevista para los Montes de Piedad, que era la única exención reconocida en la correspondiente Tabla. Y en lo que no fuese actividad típica y hubiese de venir el beneficio por su asimilación a las entidades benéficas, quedaba todo reducido al punto 26 de la Tabla de exenciones: «corridas de toros, novillos, bailes de máscaras, etcéterau. Obviamente era impensable que el Real Decreto de 14 de marzo de 1933 estableciera una exención subjetiva de la que carecían las entidades propiamente benéficas, de forma que no sólo se asimilasen las Cajas de Ahorro a estas últimas en el orden tributario, sino que fuesen más lejos, alcanzando una exención subjetiva absoluta, no susceptible de ser concedida por un simple Real Decreto.

\section{PERDURABILIDAD DEL RÉGIMEN TRADICIONAL HASTA EL TEXTO REFUNDIDO DE 1966}

Los afios que siguieron no fueron de signo distinto sino que confirmaron, sin el menor asomo de duda, las conclusiones sentadas ya para los años treinta. 
En 1941, por Orden de 29 de octubre, se aprueban nuevas Tarifas y una nueva Tabla de exenciones, sin apartarse de la Base 2. ${ }^{a}$ de las Bases de ordenación de la Contribución industrial. Si la Tabla de 1896 era notablemente parca en sus referencias a las entidades benéficas, la de 1941 era algo más expresiva, simplemente por la circunstancia de que tales entidades habían evolucionado e iniciado modestas incursiones en el mundo empresarial que son tenidas en cuenta por la Administración, pero con extremado cuidado. Así, la Tarifa 3., en su apartado de Reglas especiales, dice expresamente, alejando cualquier duda sobre una supuesta exención subjetiva de las entidades benéficas: «Las industrias que se ejerzan en los Establecimientos de corrección o presidios, satisfarán la cuota que les corresponda... En igual forma tributarán las que se ejerzan por Comunidades religiosas o establecimientos benéficos, salvo las excepciones consignadas en la Tabla». Y en la Tabla, con el n. ${ }^{\circ}$, se recoge la única exención particular de las Cajas de Ahorro: «Cajas de Ahorro y Montes de Piedad, establecidos con aprobación del Gobierno, cuyos capitales y acumulación de beneficios se emplean exclusivamente en préstamos sobre alhajas y otros efectos, sin distribución de beneficio alguno entre los fundadores. Si dichos establecimientos estuvieren creados con cualquier objeto de especulación serán considerados como Sociedades anónimas y pagarán por el concepto que les correspondan. Es decir, reproduce al pie de la letra lo que ya decía la Tabla de 1896. Pese a mediar entre ambas disposiciones el Real Decreto de 14 de marzo de 1933, no avanza un ápice el grado de exención de las Cajas de Ahorro que sigue reducida a la actividad típica de los Montes de Piedad. Se tenía muy claro, al cabo de ocho años del Decreto de 1933, que el beneficio se limitaba a los Montes de Piedad.

Pretensiones más ambiciosas en ese orden chocarían con la extrema rigurosidad que preside la Tabla respecto de otras finalidades benéficas. Así, los números 20,41 y 46 de la Tabla:

«20. Establecimientos de enseñanza costeados con fondos del Estado, de la Provincia o del Municipio, o por Fundaciones esencialmente benéficas, aunque por excepción vendan los productos de los talleres dedicados a dicha enseñanza en el mismo establecimiento, siempre que el importe de la venta sin utilidad para ningún particular o tercera persona, se destine exclusivamente a la adquisición de primeras materias o al sostenimiento de la enseñanza en el mismo establecimiento.

41. Restaurantes de obreros o asociaciones piadosas que se dedican a proporcionar alimentación a las clases obreras y necesitadas, aun cuando sea por retribución, siempre que ésta no exceda del coste de los alimentos. Si obtuviesen alguna utilidad pagarán la Contribución industrial correspondiente.

46. Talleres de zapatería, alpargatería, sastrería y cualesquiera otros, así como las reses productoras de leche que tengan los Hospitales y Casas de Beneficencia y demás establecimientos piadosos, siempre que los artículos fabricados y la leche producida sean destinados exclusivamente al consumo de los enfermos y asilados y no objeto de venta al 
público bajo ningún concepto. Los establecimientos citados y las Casas de Salud están exentas como tales, no sólo cuando sean sostenidos con fondos del Estado, la Provincia o el Municipio, sino también cuando, teniendo carácter particular, se hallen destinados exclusivamente a servicios de hospitalización o tratamiento de enfermos con absoluta gratuidad para los acogidos en ellos de todas las estancias y asistencias facultativas.»

Es más, la Ley de 16 de diciembre de 1940, de Reforma tributaria, había puesto fin a determinadas exenciones de las Cajas de Ahorros en la Contribución de Utilidades, haciéndolas tributar, según el art. 37, por el tipo del $11 \%$ (el más alto era del $25 \%)$.

No cambia el panorama con la Orden de 19 de octubre de 1950 que aprueba nuevas Tarifas y Tabla de exenciones, en cuyo n. $^{\circ} 9$ se repite una vez más, respecto de las Cajas de Ahorro y Montes de Piedad, lo que se venía diciendo desde el año 1896. No hay ampliación de los beneficios tributarios de las Cajas de Ahorros que siguen reducidos a las actividades de Monte de Piedad. La Ley de 26 de diciembre de 1957 sigue la misma tónica. En su art. 55 se establece: «Estarán sujetas al pago de la cuota fija o licencia fiscal todas las personas fisicas y jurídicas así españolas como extranjeras que ejerzan en territorio español industria, comercio, arte u oficio por cuenta propia o en comisión. Dicha cuota fija se determinará con arreglo a las Tarifas de la Contribución industrial de Comercio y Profesiones hasta ahora vigentes (la últimamente indicada) y las únicas exenciones serán las figuradas en la Tabla anexa a las mismas».

Vino después la Ley $41 / 1964$, de 11 de junio, de Reforma del sistema tributario, que en el Impuesto sobre Actividades y Beneficios comerciales e industriales (impuesto que sustituyó al de la Contribución industrial) ni una sola palabra dedica a las Cajas de Ahorro. En su art. 241 ordenaba al Gobierno aprobar por Decreto el texto refundido de las leyes de los distintos tributos regulados en la Ley. Y en la disposición final ordenaba también al Gobierno publicar la tabla de vigencias y disposiciones derogadas. La disposición transitoria primera de la Ley general tributaria de 28 de diciembre de 1963 había ya previsto estos textos refundidos: «Por el Ministerio de Hacienda, en el plazo de dos años y previo dictamen del Consejo de Estado, se propondrán al Gobierno los proyectos de Decreto en los que se refundan las disposiciones vigentes para cada tributo. Dicha refundición acomodará las normas legales tributarias a los principios, conceptos y sistemática que se contienen en la Ley general tributaria, y procurará regularizar, aclarar y armonizar las leyes tributarias vigentes, que quedarán derogadas al entrar en vigor los textos refundidos». Ninguna de estas acotaciones a que deberán sujetarse los textos refundidos (principios, conceptos, sistemática, regularización, aclaración y armonización) autorizaba la conversión de una exención objetiva y limitada en exención subjetiva y total. Sin embargo, esto es lo que hizo, ilegítimamente, el Texto refun- 
dido del Impuesto sobre Actividades y Beneficios comerciales e industriales, aprobado por Decreto de 29 de diciembre de 1966, cuando en el art. 9, apartado 7 reconoce exención a las «Cajas Generales de Ahorro Popular y Cajas Rurales Cooperativas», sin aditamento ni limitación alguna. Transgrede con ello el mandato del legislador $y$ en consecuencia hace nulo este reconocimiento de beneficio tributario en lo que excedía de la legalidad vigente que estaba limitada a los Montes de Piedad. Por contraste, las entidades propiamente benéficas sólo podían disfrutar de la siguiente exención: «Los establecimientos de enseñanza costeados con fondos del Estado, de la provincia o del Municipio, o por fundaciones esencialmente benéficas, aunque por excepción vendan los productos de los talleres dedicados a dicha enseñanza en el mismo establecimiento, siempre que el importe de la venta, sin utilidad para ningún particular o tercera persona se destine exclusivamente a la adquisición de primeras materias o al sostenimiento de la enseñanza en el mismo establecimiento» (art. 9,15 del Texto refundido). Además, podían gozar de las demás exenciones que constaban expresamente en la Tabla anexa a las vigentes Tarifas del tributo (mismo artículo apartado 17). Estas otras exenciones no eran más generosas que las de la Tabla de 1941. Sorprendentemente, la exención que, en el tira y afloja de dos ministerios (Gobernación y Trabajo), habían podido conservar las Cajas de Ahorro mediante su asimilación a las entidades benéficas cuando salieron de la órbita de lo propiamente benéfico para ingresar en el mundo financiero, se convierte por causa de este lapsus del Texto refundido en una superación desorbitada de las ventajas concedidas a las entidades benéficas. A partir del Texto refundido una Caja de Ahorros podía, desde el punto de vista tributario, dedicarse a cualquier actividad, por lucrativa y especulativa que fuese, sin satisfacer el peaje de este impuesto. Bien se comprende que el supuesto quebraba de raíz por la flagrante extralimitación cometida por el Texto refundido.

\section{ERROR PADECIDO POR EL TEXTO REFUNDIDO DE 1966}

Sobre la causa del error padecido por el Texto refundido de 1966 sólo caben hipótesis, confirmables únicamente por quien fue responsable de la rotunda referencia a las Cajas de Ahorro. Había un hecho cierto. Las Cajas de Ahorro, hasta entonces, no habían satisfecho Contribución industrial, por dos razones que se complementaban y cubrían todo su campo de actividades. Dos eran sus actividades principales: tomar dinero en depósito y entregarlo en préstamo. La primera actividad no estaba sujeta al impuesto y la segunda - Monte de Piedad - estaba declarada exenta. Las actividades sociales o benéficas, carentes de lucro según las normas de beneficencia, tampoco incidian en el hecho imponible, tal como había tenido ocasión de declarar el Tribunal Supremo en las varias sentencias reseñadas más arriba. Si algún res- 
quicio para el gravamen quedaba por causa de alguna actividad residual, en todo caso de reducido volumen relativo, era pasado por alto en la gestión de la Administración financiera del Estado, supuesto que tal ocurriese. Lo cierto es que por uno u otro motivo las Cajas de Ahorro nunca tributaron por Contribución industrial. A la vista de estas circunstancias puede explicarse la redacción del Texto refundido que intentó oficializar una realidad existente, pero cometió un error al proceder de esta forma. De una parte, pese al requerimiento de la Ley general tributaria de acomodar los textos refundido a sus principios, conceptos y sistemática, confundió la no sujeción con la exención, conceptos muy claros en aquella ley. De otra, no previó la posibilidad, que luego se hizo realidad, de que el campo de acción de las Cajas de Ahorro superase los estrechos límites entonces todavía vigentes, penetrando resueltamente en el mundo bancario, lo que vino a producirse en el año 1977.

Cualquiera que fuese la causa de esta patente extralimitación del Texto refundido, lo cierto es que se fue consolidando la idea de que las Cajas de Ahorro estaban exentas de la Contribución industrial y, después, del Impuesto sobre Actividades y Beneficios comerciales e industriales en su forma de cuota fija o de licencia fiscal. Si antes del Texto refundido las Cajas de Ahorro no pagaban Contribución industrial por causa de no sujeción o de exención, a partir del Texto refundido el hecho de no pagar se mantenía, pero la causa formal se había convertido, sobre el papel, exclusivamente, en exención absoluta total. Para el observador no conocedor del proceso histórico jurídico que había conducido a aquella exención, partiendo del, tampoco afortunado, art. $5 .^{\circ}$ del Decreto de 14 de marzo de 1933, la exención subjetiva y absoluta ha existido siempre (al menos desde 1933); sin embargo, esta apreciación es infundada. Como en no pocas ocasiones ocurre, es dificil erradicar conceptos que han penetrado fuertemente, aunque sea en contradicción manifiesta con las leyes. Tal ha sido el caso de las Cajas de Ahorro en el tema que nos ocupa. Se han realizado sutiles y sorprendentes argumentaciones de escaso poder de convicción para mantener el criterio de la exención subjetiva de las Cajas de Ahorro, pero el concepto, incrustado en el ordenamiento aunque haya sido por vía ilegítima, resiste firme y renueva sus apoyos frente a todos los intentos realizados de expulsar a tan inesperado e intruso huésped.

Para comprobar el error del Texto refundido de 1966 es de interés pararse a recordar lo que fue la reforma tributaria de 1964 (Ley 41/1964, de 11 de junio), de la que salió aquel Texto refundido relativo a la vieja Contribución industrial, después Licencia fiscal y ahora Impuesto sobre Actividades Económicas. A través de la cuota fija de licencia fiscal del llamado Impuesto industrial se enlazaba la imposición de todas las actividades económicas. El ejercicio de cualquier actividad económica estaba sujeto a la licencia fiscal que era el pórtico de la tributación de estas actividades. Las personas físicas tributaban luego 
por la cuota de beneficios de la que se deducía la cuota de licencia fiscal. Las personas jurídicas, por su parte, tributaban luego por el Impuesto sobre Sociedades de cuya cuota se deducía también la licencia fiscal satisfecha. Éste era el esquema perfectamente entrelazado, con ventaja sobre el sistema actual en que la licencia fiscal queda menos trabada con el sistema general. Cuando la ley de reforma reguló la licencia fiscal (el pórtico), lo que hizo en los arts. 61 a 63, ninguna mención dedicó a las Cajas de Ahorro, por lo que su régimen de sujeción y no exención anterior, salvo los Montes de Piedad, persistía. Por si cupiese alguna duda sobre la sujeción a la tributación por actividades económicas de las Cajas, éstas son mencionadas en el Impuesto sobre Sociedades, y no para declararlas exentas, sino para regular algunos aspectos de su tributación, entre otros, y fundamentalmente, el tipo impositivo que quedó establecido en el $16 \%$ (art. 96, b) de la Ley citada de reforma tributaria). Incluso, al mencionarlas para fijar este tipo de imposición, quizá para eliminar cualquier duda, las denomina «Cajas Benéficas de Ahorro». Era, pues, patente la voluntad del legislador de gravar la actividad económica de las Cajas de Ahorro, aun reconociendo su condición benéfica, y como primera partida de esa sujeción tributaria, plenamente consciente y querida, estaba la licencia fiscal. Con el lapsus del Texto refundido las corporaciones locales padecieron, inmediatamente (a consecuencia de los recargos perdidos) y posteriormente (a consecuencia de la pérdida de la cuota y recargos), la minoración de sus recursos, y para mayor inri, su merma de ingresos repercutió en un incremento de los de la Hacienda estatal, puesto que la cuota de licencia fiscal hubiese reducido la cuota del Impuesto sobre Sociedades (art. 97,1, a) de la Ley de reforma) y el pago de los recargos, al ser considerados gastos deducibles (art. 76, f) de la Ley), hubiese reducido también la base imponible del Impuesto sobre Sociedades y su cuota. En resumen, las Cajas, con esa reforma, no rebajaron sus aportaciones tributarias; las corporaciones locales no ingresaron cantidad alguna de las Cajas, y el Estado se benefició en igual medida en que se perjudicaron las corporaciones locales. Y todo ese desolador desenlace no procedía de la ley sino del error, digamos, del Texto refundido.

Lo que viene a continuación casi sería irrelevante si no fuese porque compone la escenografia del drama procesal que se va a desarrollar. a) El Decreto de 27 de agosto de 1977 abre a las Cajas, de par en par, las puertas del mundo financiero. b) La Ley 44/1978, de 8 de septiembre, del Impuesto sobre la Renta de las Personas Físicas, en su disposición transitoria $1 .{ }^{\mathrm{a}}, 1, \mathrm{~b}$ ) transforma en tributo local de carácter real la licencia fiscal del Impuesto industrial. c) El Real Decreto-ley 3/1981, de 16 de enero, que aprueba determinadas medidas sobre régimen jurídico de las corporaciones locales, establece en el art. 23: «1. Las exenciones tributarias concedidas por el Estatuto de 14 de marzo de 1933 y disposiciones posteriores, se entenderán limitadas, exclusivamente, en cuanto a los tributos municipales se refiere, a las actividades de los Montes de 
Piedad y benéficas expresamente declaradas, estando sujetas a los mismos las demás actividades $\mathrm{y}$, especialmente las que desarrollen como establecimientos de crédito. 2. Las Cajas de Ahorro gozarán de exención en el Impuesto Municipal sobre la Radicación por utilización de los locales destinados exclusivamente a Monte de Piedad»; este Real Decreto-ley fue convalidado y sustituido por la Ley 40/1981, de 28 de octubre, que en su art. 24,1 reproduce el art. 23 del Real Decreto-ley con ligeras variaciones de estilo pero sin cambio sustancial: «1. Las exenciones tributarias concedidas por el Estatuto de 14 de marzo de 1933, y disposiciones posteriores, se entenderán limitadas, en cuanto a los tributos municipales se refiere a los Montes de Piedad y obras Benéfico-Sociales de las Cajas expresamente autorizadas, estando sujetas a los mismos las demás actividades y especialmente las que desarrollen como establecimientos de crédito. 2. Las Cajas de Ahorro gozarán de exención en el Impuesto Municipal sobre la Radicación por la utilización de los locales destinados a Monte de Piedad y obra Benéfico-Social»». d) El Real Decreto 3183/81, de 28 de diciembre, consistente en la tabla de preceptos vigentes y derogados, establece expresamente la derogación parcial del «art. $5 .^{\circ}$ del Estatuto para las Cajas de Ahorro Popular de 14 de marzo de 1933, en cuanto a las exenciones tributarias locales concedidas, en la forma que establece el mencionado art. 24 de la ley 40/1981». e) El Real Decreto 3197/83, de 7 de diciembre, que modifica las Tarifas de Licencia fiscal de Actividades comerciales e industriales da nueva redacción, en el art. $1 .^{\circ}, 13$, al apartado 811.11, introduciendo a las Cajas de Ahorro en el epígrafe de los bancos en los siguientes términos: «Bancos o banqueros y Cajas de Ahorro, considerándose como tales los que de acuerdo con la legislación de ordenación bancaria o con la normativa de las Cajas de Ahorro, respectivamente, realizan las operaciones propias de los mismos». f) Esta modificación queda sin efecto en virtud del Real Decreto 883/1985, de 19 de abril, que restaura la anterior redacción del epígrafe 811.11 con supresión de la referencia especial a las Cajas de Ahorro. g) La Ley 7/1985, de 2 de abril, de Bases del Régimen local, que no contiene normativa sustantiva en cuanto a los tributos locales, en la disposición final primera «autoriza al Gobierno de la $\mathrm{Na}$ ción para refundir las disposiciones legales vigentes de acuerdo con lo dispuesto en la disposición derogatoria. La refundición comprenderá también la regularización, aclaración y armonización de dichas disposiciones»; emplea, pues, la fórmula (regularización, aclaración y armonización) estereotipada por la Ley general tributaria. h) El Real Decreto legislativo 781/1986, de 18 de abril, aprueba ese texto refundido del régimen local. En su art. 279,7 establece, en cuanto a la licencia fiscal, la siguiente exención: «Las Cajas Generales de Ahorro Popular, por los Montes de Piedad y obras Benéfico-Sociales», y en la disposición derogatoria, apartado undécimo, deroga, entre otros, el Texto refundido del Impuesto sobre Actividades y Beneficios comerciales e industriales aprobado por Decreto de 29 de diciembre de 1966. Es el punto final del plano normativo. 


\section{LAS SENTENCIAS DEL TRIBUNAL SUPREMO}

El drama jurídico-procesal tiene tres actos. En el primer acto se dictan por el Tribunal Supremo dos sentencias /1/ de 14 de mayo de 1984 (2887) y /2/ de 14 de julio de 1986 (4355), en las que se viene a declarar que las Cajas de Ahorro disfrutan de exención subjetiva total en el Impuesto de Licencia Fiscal. En el segundo acto, también por el Tribunal Supremo se dictan otras dos sentencias /3/ de 18 de octubre de 1986 (5312) y /4/ de 26 de febrero de 1987 (952), que declaran la sujeción y no exención de las Cajas de Ahorro a la licencia fiscal salvo en sus actividades de Monte de Piedad y obras sociales. El tercer acto lo componen sendas sentencias $/ 5$ y $6 /$ de la Sala de Revisión, ambas de 19 de mayo de 1988 (3899 y 4748), que dejan sin efecto las dos anteriores que habían declarado la sujeción y no exención.

A) Sentencias favorables a la exención subjetiva

\section{Sentencia /1/}

Se apoya en el Texto refundido de 1966 que, dice la sentencia, «establece que están exentas de licencia fiscal las Cajas de Ahorro popular, concordantemente con la exención que a dichas Cajas había sido reconocida en el art. 5. del Estatuto aprobado por Decreto de 14 de marzo de 1933».

(No hay tal. El beneficio tributario careció de ese alcance, como antes se ha visto. El Texto refundido de 1966 se excedió manifiestamente de la legalidad vigente contenida en las Tablas de exención de la Contribución industrial de 1896, 1941 y 1950);

añade la sentencia: «la exención legal así reconocida sólo puede quedar sin efecto en virtud de ley, como exige el art. 10,b) de la Ley general tributaria $230 / 1963$, de 28 de diciembre, concretando a este efecto la misma ley, en su art. 14, que la modificación de una exención tributaria requerirá que el Ministerio de Hacienda haya expuesto previamente al Gobierno, en Memoria razonada, la finalidad del beneficio tributario y la previsión cifrada de sus consecuencias en los ingresos públicos».

(La sentencia recuerda el principio de legalidad impuesto por la Ley general tributaria, pero olvida el de legalidad impuesto por la Ley de Administración y Contabilidad del Estado de 1911, vigente cuando se publicó el Decreto de 1933, por lo que éste no pudo exceder la Tabla de exenciones de 1896, y si lo hizo careció de validez la exención así decretada). 
Y termina la sentencia: «y según el siguiente art. 16, toda modificación de ley o reglamentos tributarios contendrá una relación completa de las normas afectadas»".

(Nada que decir, salvo que se eleve ese mandato a condición de validez de las normas, tesis inaceptable especialmente en cuanto a las que tengan rango de ley pues convertiría a la general tributaria en una especie de súper ley o la elevaría a un nivel cuasi constitucional, naturaleza que naturalmente no ostenta).

Las consideraciones anteriores de la sentencia son una simple preparación para el argumento en que se apoya. La línea discursiva real va por el siguiente camino. a) El Texto refundido de 1966 recoge la exención total y absoluta de las Cajas en cuanto a la licencia fiscal. b) El art. 24 de la Ley 40/1981 limitó las exenciones tributarias concedidas por el Estatuto de 1933 en cuanto a los tributos municipales, a los Montes de Piedad. c) La licencia fiscal, en virtud de la Ley 44/1978, se transformó en un tributo local de carácter real cuya gestión estará a cargo del Estado. d) No hay identidad entre tributo municipal y tributo local de carácter real. e) Ergo: la Ley 40/1981 no se refería a la licencia fiscal.

Este hilo argumental cuyos puntos débiles saltan a la vista, lo refuerza la sentencia con consideraciones de esta índole. $f$ ) Que así lo ha entendido el legislador por cuanto que en la Tabla de vigencias y derogaciones del Real Decreto $3183 / 1981$, de 29 de diciembre, no se hace referencia al Texto refundido de 1966 de la licencia fiscal. g) Que esta omisión debe interpretarse a favor de la vigencia del Texto refundido de 1966, pues en forma alguna es presumible el olvido. h) Que no se observa incompatibilidad entre la limitación impuesta por la ley de 1981 y la subsistencia de la exención subjetiva absoluta.

En realidad, lo único firme en la sentencia es la falta de identidad entre las expresiones tributo municipal y tributo local. En el orden terminológico-conceptual, es ello cierto, porque lo municipal es local, pero no todo lo local es municipal; por lo que una limitación afectante a los tributos municipales no puede afectar a uno que haya sido calificado de local. Se relacionan vocablosconcepto en una pura lógica matemática que sólo tiene valor para los números, cuyo significado es inequívoco, pero que es inaplicable en todas las demás ramas del razonamiento. Porque, si bien municipal no es lo mismo que local, puesto que lo local puede ser municipal o provincial y, aun más cosas; lo localmunicipal es municipal, porque lo local es el género y lo municipal es la especie. El peligro del dogmatismo es jugar con conceptos de supuesta significación inequívoca, pero que en la realidad no son tal. Cuando la licencia fiscal se convirtió en un tributo local se estaba convirtiendo en un tributo municipal, aparte de los recargos provinciales. Por eso se utilizó la palabra local, por las connotaciones 
extramunicipales que tenía o podía tener, pero su naturaleza era la de ser un tributo municipal de la misma forma que, antes, era estatal no obstante soportar importantes recargos municipales y también provinciales.

El argumento utilizado por la sentencia es pues sumamente quebradizo. Tan es así que incluso las sentencias de revisión citadas más arriba (/5 y $6 /$ ), refiriéndose a este argumento lo califican de discutible («y si bien la sentencia de 14 de mayo de 1984» —dicen ambas sentencias de revisión- «podría resultar discutible sobre la adecuación de la doctrina aplicable, al hallarse fundamentadas en la distinción entre impuestos locales y municipales y en la no derogación expresa del apartado $7 .^{\circ}$ del art. 9..$^{\circ}$ del texto refundido del Impuesto de la licencia fiscal, resulta incuestionable...», etcétera). La interpretación del problema jurídico planteado no debió quedar circunscrito a los solos vocablos sino superarlos según lo previsto en el art. $3 .^{\circ} \mathrm{del}$ Código civil. No sólo era patente la voluntad del legislador de reforzar las haciendas municipales, sino que un ligero recorrido histórico habría revelado la trampa sobre que se asentaba la exención subjetiva absoluta del Texto refundido de 1966 y una rápida mirada hacia las entidades benéficas, de las que la exención de las Cajas era mero reflejo, hubiese evidenciado la improcedencia de llevar la exención de las Cajas de Ahorro a los términos absolutos que recogió indebidamente el texto refundido.

\section{Sentencia $/ 2 /$}

A raíz de la Ley 40/1981, de 28 de octubre, por la que se limitaba el beneficio de las Cajas de Ahorro a las actividades de Monte de Piedad y obras sociales, el Gobierno por Real Decreto de 7 de diciembre de 1983 (3197/83) incorporó la referencia a las Cajas en las Tarifas de la licencia fiscal, en el apartado 811.11. Lo que de por sí evidencia que la Administración que preparó aquella ley tenía perfecta conciencia de que en virtud de la misma, a partir de entonces, las Cajas de Ahorro debían tributar por licencia fiscal, desautorizando en buena medida la hipótesis interpretativa que al cabo de un tiempo había de utilizar la sentencia antes examinada en el sentido de que no debía atribuirse a olvido el silencio de la Tabla de derogaciones respecto del Texto refundido de 1966, sino a la consideración de que aquel texto quedaba integramente vigente y, por tanto, también la exención subjetiva absoluta. Si tenemos en cuenta que ambos textos, el de la tabla derogatoria $(3183 / 81)$ y las nuevas Tarifas (3197/83), proceden de la Administración y de su máximo órgano, el Consejo de Ministros, bien se comprende que si alguna hipótesis se puede lanzar acerca de la omisión derogatoria del Texto refundido de 1966 es la de que, o bien fue olvido involuntario, o bien se juzgó innecesario ante la evidencia de los términos limitativos con que se pronunció la Ley 40/1981 acerca del Estatuto de 1933, lo que permitía evitar la alusión al texto refundido que, si en algún punto 
se apoyaba para declarar la exención, era en el Estatuto de 1933; a añadir que, en rigor, no se trataba de declarar una derogación sino de adaptar a la nueva realidad de las Cajas, cuando habían cambiado radicalmente sus actividades, el criterio de exención de 1933.

Pero vayamos a la segunda de las sentencias. Ante la nueva Tarifa que incluía a las Cajas de Ahorro, la Confederación de Cajas de Ahorro interpuso recurso de reposición contra el Decreto modificador (RD 7 de diciembre de 1983), que fue desestimado por acuerdo del Consejo de Ministros de 20 de junio de 1984. Contra esa desestimación, la Confederación de Cajas de Ahorro interpuso recurso contencioso-administrativo que dio lugar a la sentencia que ahora examinamos. Su único fundamento es el allanamiento de la Administración. El Letrado del Estado - relata la sentencia-aportó certificación en la que consta autorización para el allanamiento. Declara además la sentencia, en cumplimiento de lo dispuesto en el art. 88 de la Ley de la jurisdicción contencioso-administrativa, que no se advierte que tal allanamiento suponga infracción manifiesta del ordenamiento jurídico, añadiendo que esa posición procesal de la Administración no hace sino acomodarse a lo decidido por esta misma Sala, en sentencia recaida en recurso extraordinario de apelación y datada en 14 de mayo de 1984 (2887). Es la anteriormente examinada.

En resumen en este primer round, tenemos, en la primera sentencia, unos fundamentos tan endebles que incluso serán puestos más adelante en cuestión por la Sala de Revisión; y en la segunda, un allanamiento. Allanamiento de la Administración, no del legislativo que aprobó la ley; lo cual puede ser formalmente correcto, pero no deja de despertar alguna reserva si tal allanamiento se entiende como expresión de la voluntad del legislador, y más si beneficia justamente a la parte que se allana - la Administración del Estado- y perjudica a terceros - en este caso, las corporaciones locales-. De otra parte, el allanamiento es en cuanto a la aprobación de unas Tarifas, no en cuanto al significado y alcance de la Ley 40/1981; las Cajas no necesitaban de un epígrafe especial, pues les bastaba el epigrafe relativo a las actividades bancarias, por razón de las cuales habían de tributar a partir de 1977 cuando fueron autorizadas para realizar operaciones de esta clase. rro

B) Sentencias favorables a la sujeción y no exención de las Cajas de Aho-

Sentencia /3/

El 27 de febrero de 1984, antes pues de dictarse las dos sentencias anteriores, la Sala de lo Contencioso de Valladolid desestima recursos interpuestos por la Caja de Ahorros de Zamora contra la resolución del Tribunal Económico-administra- 
tivo Provincial que desestimó la reclamación deducida por la expresada Caja contra liquidaciones practicadas por licencia fiscal. Como se ve, la Administración, en los estratos de gestión y reclamación actúa como un bloque compacto. Entiende que las Cajas están sujetas al tributo. También lo entiende la Sala de Valladolid y también lo entenderá el Tribunal Supremo que desestimará el recurso.

El recurso es interpuesto por la Caja con el doble fundamento de la no sujeción y exención. En cuanto a la no sujeción la sentencia contiene un impecable razonamiento, desestimando la alegación del recurso en los siguientes términos: «Establecida la tesis de la recurrente es necesario no olvidar la dual cualidad de que participa el desarrollo de la actividad de estas entidades, perfectamente compatibles pero que constituyen la singularidad de su proceder y lo que permite la aplicación objetiva del tributo que motiva la liquidación girada, y así, es perfectamente concebible una actividad meramente benéfico-social en cuanto que son entes que se crean con esa finalidad específica y al amparo de la normativa que le atribuye tal condición -art. 3 Ley de 29 junio 1980 , confirmada por otras anteriores y posteriores que le atribuyen la calificación de benéfico-sociales - pero el desarrollo de esa actividad no empece que para la consecución objetiva de medios, se realicen una serie de actuaciones, servicios, que constituyen la razón motivadora del hecho imponible de acuerdo con la regla 3. ${ }^{a}$ de la Instrucción para la Licencia Fiscal de Actividades Comerciales e Industriales - Real Decreto 791/1981, de 27 de marzo-, ya que estos "servicios" ejecutados por cuenta propia o por cuenta ajena en comisión implican una serie de operaciones propias de instituciones financieras que conllevan ínsita un estímulo económico connatural con las operaciones que se ejecutan, y en consecuencia, caen de lleno en la licencia fiscal objeto de liquidación, criterio que ha sido mantenido por diversas resoluciones de este Tribunal, que por constituir doctrina definida, huelga su enumeración, no obstante la misma se confirma en la sentencia de revisión de 14 de mayo de 1984» (2887). La desconcertante invocación a esta sentencia de 14 de mayo de 1984, es perfectamente correcta en cuanto que esa sentencia aludida declara la exención pero implícitamente afirma la sujeción. El único defecto en la referencia a la repetida sentencia de 1984 es que la califica de revisión cuando era sentencia a un recurso extraordinario de apelación en interés de Ley.

La petición subsidiaria de exención fundada en la peregrina distinción ya vista entre tributo local y tributo municipal, la sentencia la desestima con unos razonamientos que posiblemente por defectuosas transcripciones resultan confusos. En todo caso - hay que decirlo- no aparecen argumentos sólidos en favor de la no exención, quizá por causa de su evidencia a la vis- 
ta de la Ley 40/1981 y lo deleznable de la distinción entre local y municipal que se invocaba por la Caja como fundamento de la opinión contraria.

Sentencia $/ 4 /$

Es un calco de la anterior, tanto en los antecedentes de hecho como en los fundamentos de derecho. Nada nuevo aporta, salvo confirmar la tesis de la $/ 3 /$.

\section{C) Sentencias de la Sala de Revisión}

Las sentencias $/ 3$ y $4 /$ fueron objeto de recurso extraordinario de revisión que dieron lugar a otras dós, ambas de la misma fecha, idénticas en sus razonamientos aunque más extensa la primera.

El dispositivo de ataque de las Cajas de Ahorro se asienta en las sentencias $/ 1$ y $2 /$. La defensa de la Administración es penosa. Comienza por aceptar que las Cajas de Ahorro estaban exentas de licencia fiscal en virtud del art. $4 .{ }^{\circ}$ del Estatuto de 14 de marzo de 1933. Se confunde con ello el Decreto de 14 de marzo de 1933 (Gaceta del 16) que se refiere al Instituto de Crédito de las Cajas de Ahorro Popular, en cuyo art. $4 .^{\circ}$ se establece una exención absoluta a esa institución (gozará de absoluta exención fiscal), con el Decreto de la misma fecha (pero Gaceta del día 17) que, éste sí (pero no en el art. $4 .^{\circ}$ sino en el $5 .^{\circ}$ ), establece una exención menos rotunda y más discreta en favor de las Cajas. Sigue la defensa de la Administración reconociendo, consecuentemente, la legitimidad del Texto refundido cuando reconoció la exención subjetiva absoluta. Para terminar afirmando que la Administración tuvo dos actuaciones que hicieron que la cuestión resultase dudosa: de una parte, no mencionó en la Tabla de derogaciones al Texto refundido; de otra, no actualizó las Tarifas incluyendo a las Cajas hasta 1983. La defensa de la posición de las Cajas de Ahorro, no la hizo la recurrente, pues se limitó a invocar las sentencias $/ 1$ y $2 /$, la asumió la propia Administración con unas alegaciones ausentes de convicción y poniendo al descubierto aparentes puntos flacos que en realidad no existian.

La sentencia de la Sala de Revisión, tras reconocer que podria resultar discutible el argumento de la distinción entre tributo local y tributo municipal de la sentencia $/ 1 /$, así como la no derogación expresa del texto refundido de 1966 , lo que resulta incuestionable, a su entender, es que la sentencia $/ 2 /$, no se produce tan sólo por un análisis legal de la Sala, sino como consecuencia del allanamiento de la Administración. La importancia de este allanamiento es tanta que en el fundamento de derecho $5 .^{\circ}$ la sentencia llega a decir que en la disyuntiva entre las sentencias de 14 de mayo de 1984 y de 18 de octubre de 1986, (podía haber) proclamado la tesis de ésta sostenida como la adecuada 
(es decir, la sujeción y no exención), pero no lo es menos que ello, cual se ha indicado, ya no es factible tras la sentencia de 14 de julio de 1986 (la /2/) y de la actitud adoptada en el proceso donde ésta se pronunció por la Administración.

\section{LA OCASIÓN PERDIDA}

El drama sin embargo todavía no ha terminado. Tiene una segunda parte. Alguna corporación local —en el caso conocido, el Ayuntamiento de Castellón-, pese a la doctrina de la Sala de Revisión del Tribunal Supremo, practicó varias liquidaciones a Cajas de Ahorro por el Impuesto sobre Actividades Económicas correspondientes al período de prórroga de las exenciones de la licencia fiscal. El Tribunal Superior de Justicia de Valencia replantea la cuestión con base al siguiente argumento. Si el efecto derogador de la Ley 40/1981 podía objetarse por la falta de alusión del Texto refundido de 1966, una vez dictado el Real Decreto legislativo 781/1986, que en el art. 279,7 redujo la exención de las Cajas de Ahorro, en la licencia fiscal, a los Montes de Piedad y obras benéfico-sociales y que en la disposición derogatoria derogó el Texto refundido del Impuesto sobre Actividades y Beneficios Comerciales e Industriales de 29 de diciembre de 1966, no puede oponerse ninguna objeción a liquidaciones correspondientes a períodos posteriores a tal texto normativo, pues todos los requisitos, a efectos derogatorios, se han cumplido respecto de la exención del Estatuto de 1933. Esta sentencia es de 27 de abril de 1994. Sin duda fue recurrida, con solución de momento no conocida.

El Real Decreto legislativo 781/1986 fue objeto de múltiples recursos ante el Tribunal Supremo. La Confederación Española de Cajas de Ahorro lo impugnó precisamente por este artículo 279,7 que limitaba la exención de las Cajas a los Montes de Piedad y Obras benéfico-sociales. El Tribunal Supremo, sin embargo, en su sentencia de 3 de febrero de 1997, ha optado por no entrar de frente en la cuestión, con el argumento de que al estar incluida esta disposición en el Titulo VIII del Texto Refundido, que ha sido derogado por la Ley 39/1988, de 28 de diciembre, de Haciendas Locales, es procedente desestimar el recurso por falta de objeto. Largo sería enjuiciar esta opción del Tribunal Supremo. Lo único importante, a nuestros efectos, es que al no haberse resuelto de raiz sobre la validez o no del art. 279,7, las espadas siguen en alto. Y cada recurso, cada litigio, puede hacer una valoración distinta de esta pieza fundamental del rompecabezas jurídico planteado, si bien con alguna ventaja para el ángulo municipalista, puesto que el cuestionado Real Decreto legislativo, en lo que particularmente concierne a su art. 279,7 , ha quedado incólume. 
En alto están las espadas y se cruzan con variada suerte en la aplicación que en cada caso concreto se hace del Real Decreto legislativo de 1986. La sentencia del Tribunal Supremo de 10 de febrero de 1995 fue poco favorable a la tesis municipal. Sabido es que en el ya no vigente Impuesto sobre Radicación la cuota venía modulada por la de Licencia Fiscal. La impugnación sobre una liquidación de este impuesto llegó al Tribunal Supremo que dictó sentencia en la fecha indicada, en la que, respecto del tema lateral de la Licencia Fiscal de influencia indirecta en el caso, formula la siguiente doctrina: a) Las Cajas de Ahorro siempre han venido disfrutando, con relación a la totalidad de las actividades, del beneficio de exención de la licencia fiscal. b) Así lo recogió el Texto refundido de 1966. c) A raíz de la publicación de la Ley 40/1981 la Administración trató de inferir del contexto del art. 24 la derogación de la citada exención. đ) El Tribunal Supremo en la sentencia de 14 de mayo de 1984 (la 11/) desautorizó tal interpretación. e) Antes de dictarse esta sentencia la Administración incluyó en las Tarifas de Licencia fiscal a las Cajas de Ahorro, lo que fue recurrido por la Confederación de las Cajas de Ahorro. f) Pero antes de dictarse sentencia en este último recurso, la Administración mediante Real Decreto 883/1985, de 19 de abril, rectificó y excluyó a las Cajas de Ahorro de las Tarifas de Licencia fiscal. g) Fue dictada sentencia en el recurso. e) Estimando la pretensión de la Confederación de las Cajas de Ahorro. h) Con posterioridad, el Tribunal Supremo ha dictado nuevas sentencias confirmatorias de la exención. i) La exención del Texto refundido de 1966 no fue derogada por la Ley 40/1981 por lo que la derogación efectuada por el Real Decreto legislativo $781 / 1986$ es ineficaz por carecer de rango. j) El Gobierno se excedió en el Real Decreto legislativo pues no pudo derogar lo que no había derogado una ley. $k$ ) La vigencia de la exención ha sido reconocida por el propio Gobierno en virtud de f).

La madeja, a las alturas del 10 de febrero de 1995, no podía quedar más enredada. La claridad deseable en la redacción, interpretación y cumplimiento de los textos legales, ha sido sustituida por una notable confusión en la que incurre, de un lado, la Administración, en la preparación de los proyectos de ley y en la aprobación de los Reales Decretos y, de otro, los órganos jurisdiccionales que afiaden confusión a la confusión, contradiciéndose lamentablemente y sin aportar un discurso preciso y coherente consigo mismo. El elemento sufridor o sujeto pasivo o paciente de esta confusión difícil de describir, son las corporaciones locales que ven sus nunca boyantes economías mezcladas en ese conflicto jurídico procesal en que no han tenido participación.

Las precedentes afirmaciones de la sentencia sobre las que se asienta el fallo suscitan las siguientes observaciones. $A$ la a). Las Cajas de Ahorro no pagaron nunca el tributo, pero no en virtud de una exención total de la que nunca disfrutaron, sino porque la única actividad al principio gravable, la de préstamo con ga- 
rantía prendaria, ésta sí que estaba exenta por ser actividad de Monte de Piedad; las demás actividades eran estrictamente benéficas, sin percepción de ingresos ni obtención de utilidades, por lo que no estaban sujetas. Cuando sus actividades financieras se extendieron, debieron pagar porque nunca fueron declaradas exentas. La tolerancia de la Administración (epigrafes siempre existieron para que fuese posible su tributación o debieron crearse por la Administración según preveía el reglamento) ni equivale a exención ni genera un derecho a ella ni aun por prescripción inmemorial que evidentemente no concurría, por cuanto que el exceso de actividades sobre lo estrictamente benéfico no comenzó hasta muy entrado el presente siglo. $A$ la $b$ ). En consecuencia, el Texto refundido de 1966 recogió la exención indebidamente, por lo que cuantas consideraciones hace la sentencia sobre la ineficacia de los excesos de los decretos legislativos y textos refundidos debe aplicarse al de 1966 que claramente se excedió de los límites inherentes a su cometido al innovar una exención nunca declarada por texto con rango de ley. A la c). No cabía derogar lo que nunca estuvo vigente. La Administración si hasta entonces había actuado con desusada tolerancia hacia las Cajas de Ahorro, en aquel momento intentó reconstruir su actuación a los estrictos mandatos de la ley. $A$ la $d$ ). La sentencia de 14 de mayo de 1984 fue puesta en entredicho en cuanto a sus fundamentos por las de revisión luego dictadas. $A$ la e). Actuación de la Administración plenamente correcta a tenor de lo anterior. $A$ la fl). Aquí la Administración reinicia su actuación incorrecta. $A$ la g). Forma parte del punto anterior. El fundamento de esta sentencia, como en la misma expresamente se manifiesta, es el allanamiento del representante de la Administración. Un allanamiento que suscita una cierta perplejidad, especialmente en sus efectos, por cuanto que las consecuencias económicas habían de repercutir sólo en las haciendas locales, no en la del Estado que por el contrario salía beneficiado. $A$ la $h$ ). Forma parte del punto anterior. $A$ la $i$ ). La afirmación sólo puede asentarse en el sutil y erróneo argumento desautorizado por la Sala de Revisión, de que los términos municipal y local no son idénticos. Lo eran atendida la voluntad evidente del legislador, tanto de 1981 (que limitó la exención en los tributos municipales) como de 1978 (que transformó la licencia fiscal en tributo local de carácter real), de reforzar la hacienda municipal; las dos leyes respondían a un mismo designio con efectos derivados indirectos respecto de las haciendas provinciales. A la j). El Gobierno no se excedió en el Real Decreto legislativo de 1986, pues desde siempre la única exención en la Licencia Fiscal y su antecedente el Impuesto industrial alcanzaba, sólo y monótonamente, a los Montes de Piedad, con la única excepción -inválida por ilegal— del Texto refundido de 1966. A la $k$ ). El Gobierno una vez más erró como pone en evidencia lo anterior. Los argumentos ad hominem carecen en absoluto de valor, y más a la hora de interpretar la voluntad del legislativo por actos de la Administración. 


\section{EL VIRAJE INICIADO POR EL TRIBUNAL SUPREMO}

Por contraste, últimamente han sido dictadas por el Tribunal Supremo tres sentencias, de 24 de mayo, 8 de junio y 14 de julio de 1996, las tres de idéntico contenido, tanto en cuanto a la cuestión suscitada - Impuesto municipal sobre el Incremento del Valor de los Terrenos-, como a las consideraciones, fundamentos jurídicos y fallo, que abre nuevas perspectivas, no sólo en el recurrente tema de la tributación de las Cajas de Ahorro, sino en el más general de interpretación de cierto tipo de exenciones. Tienen especial valor estas sentencias, primero, porque siguiendo los dictados de la Ley general tributaria implican una aplicación rigurosa de las exenciones; en segundo lugar, porque el método seguido de intepretación huye de la literalidad de los textos para desentrañar su sentido a través de la voluntad que los mueve; y tercero, porque viene a establecer una regla para la interpretación de los beneficios tributarios genéricos, distinta de la aplicable a los beneficios tributarios específicos.

\section{Tributación de las Cajas de Ahorro}

1) Comienza por afirmar que «el art. 24,1 de la Ley $40 / 1981$ concede exención en los tributos locales a las Cajas de Ahorro únicamente en lo que se refiere a los Montes de Piedad y obras Benéfico-sociales, declarando sujetas a los mismos el resto de sus actividades». Este párrafo suscita la primera reflexión. El Tribunal Supremo, fijando en la memoria, sin tener a la vista el texto, pone en boca del controvertido art. 24 de la Ley 40/1981 la expresión tributos locales, no la expresión que emplea el texto legal de tributos municipales; lo que evidencia que a estos efectos (los de la Ley 40/1981) ambas expresiones son idénticas; cuando precisamente su distinción sirvió de base a las sentencias adversas a la Administración.

2) De lo anterior extrae la consecuencia de que al ser onerosa la transmisión objeto de litigio, produce un claro lucro a la entidad vendedora, sometido a gravamen. El Tribunal Supremo huye de la invocación tan repetida, de que la entidad, en su actividad global no persigue el lucro, pues sus excedentes se destinan a obras benéfico-sociales. Lo importante es la operación en sí, si es onerosa o de carácter gratuito. En el primer caso está sometida a gravamen. También tiene en cuenta el dato de si la finca está o no afectada directamente a un fin benéfico-social.

3) El art. 353,1,d) del Real Decreto legislativo 781/1986, de 18 de abril, establecía la exención en términos absolutos para las instituciones que tengan la calificación de benéficas o benéfico-docentes (recuérdese que estamos en Plus Valía). En esto se basaba el recurso de las Cajas. El Tribunal Supremo re- 
plica que tal matización, la de afectar la exención sólo a los Montes de Piedad, está en los otros tributos locales, por lo que debe aplicarse también al Impuesto sobre Incremento del Valor de los Terrenos, pues, con abstracción de ser perfectamente aplicable al mismo la filosofia aplicable a aquéllos (sentencia de esta Sala de 27 de noviembre de 1990), porque es ésta la conclusión más lógica, el criterio que definitivamente debe aceptarse no puede ser otro, de acuerdo con la doctrina analizada, que el de entender que se ha producido una "simbiosis» entre los arts. 24,1 de la Ley 40/1981 y 353,1, d) del Real Decreto legislativo 781/1986. Se reconoce, pues, el extraordinario valor y fuerza del art. 24,1 de la Ley 40/1981 que se proyecta, como no podía ser menos, sobre el Real Decreto legislativo de 1986. Las otras consideraciones de este párrafo las dejamos para más adelante.

4) Afirma seguidamente la sentencia: «En el caso presente, no se da motivo alguno que justifique la exención, por cuanto es indudable que tienen carácter comercial las adquisiciones de las fincas de autos, como lo tienen, en general, las operaciones mercantiles y bancarias realizadas por las referidas Cajas en sus oficinas y sucursales, máxime cuando, desde el Real Decreto de 27 de agosto de 1977, pueden realizar las mismas operaciones que las autorizadas a la Banca privada, según al efecto dispone su art. 20\%. Tales consideraciones (y con mayor motivo) eran plenamente aplicables a la licencia fiscal que justamente grava las operaciones mercantiles y bancarias, las mismas operaciones (de las Cajas) que las autorizadas a la Banca. Desde 1977, pues estaban sujetas las Cajas a los mismos epígrafes de la Banca. Antes estaban sujetas a los que correspondiese a cada actividad en sí mismo considerada.

\section{Método interpretativo}

En contraste con las sentencias que certificaron la exención subjetiva absoluta de las Cajas de Ahorro en la licencia fiscal, en estas tres relativas al Impuesto municipal sobre Incremento del Valor de los Terrenos, no se utiliza el método conceptual de aquéllas, apegado estrechamente a la literalidad de las normas en su más superficial y elemental significado, sin profundizar en su sentido a la vista de cuantos factores recomienda para la labor intepretativa el Código civil, sino que, por el contrario, pasa por encima de la pura literalidad, al intercambiar desenfadadamente los términos municipal y local, cuya distinción constituyó la causa decidendi de aquéllas. Y deja también de lado las actitudes procesales, como el allanamiento, ajenas a la función interpretativa de las normas, entregándose de lleno a una búsqueda porfiada de la voluntad del legislador. Compara los preceptos de exención del Texto refundido de 1986 respecto de los diversos impuestos municipales y comprende que la disonancia de un impuesto, sin justificación aparente, debe corregirse en armonía con lo expresado, 
de una misma forma, en todos los demás impuestos, limitando pues la exención en el Impuesto sobre Incremento de Valor de los Terrenos sólo a las actividades de Monte de Piedad y obras benéfico-sociales tal como ocurre en los demás impuestos regulados por el Texto refundido de 1986. Todas las normas deben participar de una misma filosifia. Lo impone la lógica. En fin, por un proceso de simbiosis, de comunicación necesaria, el art. 24 de la Ley 40/1981 debe infundir su voluntad evidente a todas las normas tributarias locales. La sentencia no hace sino honrar al legislativo, alejando cualquier interpretación que implique arbitrariedad. Y el legislador sería arbitrario, y con esto termina su discurso, si reconociese la exención, sin causa justificada y manifiesta, a una actividad tan lucrativa como la transmisión de fincas a título oneroso y, por extensión, diremos nosotros, a actividades que en nada se distinguen de las bancarias y están en el punto extremo, aunque sea legítimo, de la más pura especulación.

\section{Distinción entre exenciones genéricas y específicas}

Una cosa son las exenciones específicas, a una entidad determinada, designada por un nombre, y otra, las exenciones genérivamente enunciadas por razón de una determinada causa, las cuales serán disfrutadas por las entidades que cumplan con la condición genérica establecida, lo cual es evidente. Pero afina más la sentencia: exige, no sólo que la entidad cumpla con la condición genérica impuesta por la ley, sino que además el bien o actividad sujetos al tributo, el bien concreto o la actividad concreta, cumplan con la causa de la exención. Esta regla es de amplio y largo alcance en muchos y extensos campos del Derecho tributario. Si la exención se concede por causa de la naturaleza benéfica de la entidad, no basta que el bien o la actividad pertenezca o sea atribuible a la entidad tenida por benéfica y declarada incluso como tal, es preciso que el bien esté al servicio directo de los fines benéficos y la actividad en sí sea benéfica. No se extenderá la exención, en el caso de las Cajas de Ahorro, a bienes que no estén al servicio directo de Monte de Piedad o de obras benéfico-sociales, ni a las actividades que no sean también de Monte de Piedad o benéficosociales. Se rechaza la transmutación en benéficos de bienes o actividades no específicamente benéficos. Esta línea marca con exactitud una orientación que puede felizmente acabar con inseguridades y oscilaciones interpretativas anteriores que en el último término denotaban la ausencia de un criterio definido acerca del alcance y términos de la exención reconocida por la ley de esa forma genérica, y que en ocasiones, no poco frecuentes, extendían el ámbito de la exención más allá del fin protegido bajo el pretexto de que los bienes y las actividades estabain al servicio indirectamente del fin protegido. En realidad, esta orientación es la que está marcando con claridad el legislador en las últimas normas dictadas en materia de beneficios tributarios, siendo exponentes de ca- 
lidad la Ley 30/1994 sobre Fundaciones y la Ley de Impuesto sobre Sociedades de 1995. No cabe duda que esta orientación, tan sabiamente adoptada por el legislador y $\tan$ prudentemente seguida por la jurisprudencia, supone un replanteamiento de toda la espinosa cuestión de los beneficios tributarios, que no consisten en una graciosa e indolora renuncia o perdón de los entes públicos, sin otro quebranto, sino en una evidente redistribución entre los demás contribuyentes de la carga falsamente redimida.

\section{PROTECCIÓN DE LA AUTONOMÍA LOCAL}

Es sabido que la Constitución espanfola garantiza la autonomía de los municipios (art. 140). La Ley 7/1985, de 2 de abril, reguladora de las Bases de régimen local, en su art. 63,3 establece que «las entidades locales territoriales estarán legitimadas para promover, en los términos del art. 119 de esta Ley, la impugnación ante el Tribunal Constitucional de Leyes del Estado o de las Comunidades Autónomas cuando se estime que son éstas las que lesionan la autonomía constitucionalmente garantizada». El aludido art. 119 dispone por su parte que la Comisión Nacional de Administración Local, integrada por un número igual de representantes de las entidades locales y de la Administración del Estado, «podrá solicitar de los órganos constitucionalmente legitimados para ello la impugnación ante el Tribunal Constitucional de las Leyes del Estado o de las Comunidades Autónomas que estime lesivas para la autonomía local garantizada constitucionalmente. Esta misma solicitud podrá realizarla la representación de las Entidades locales en la Comisións. Y según el art. 162.1.a) de la Constitución uestán legitimados para interponer el recurso de inconstitucionalidad, el Presidente del Gobiemo, el Defensor del Pueblo, cincuenta Diputados, cincuenta Senadores, los órganos colegiados ejecutivos de las Comunidades Autónomas, y en su caso, las Asambleas de las mismas». El otro camino de garantía es la cuestión de inconstitucionalidad del art. 35,1 de la Ley Orgánica 2/1979, de 3 de octubre, reguladora del Tribunal Constitucional: «Cuando un Juez o Tribunal, de oficio o a instancia de parte, considere que una norma con rango de Ley aplicable al caso y de cuya validez dependa el fallo pueda ser contraria a la Constitución, planteará la cuestión al Tribunal Constitucional con sujeción a lo dispuesto en esta Ley». El acceso, pues, de las corporaciones locales al Tribunal Constitucional en garantía de su autonomía frente a las leyes, debe superar en todo caso un filtro, consistente, en cuanto al recurso de inconstitucionalidad, en el acogimiento previo de su petición por alguno de los cuatro órganos o grupos sefialados, y en cuanto a la cuestión de inconstitucionalidad, en la también previa consideración favorable del tribunal o juez ordinario que entienda el asunto. 
Sin embargo, no parece ser una vía de esta clase, condicionada a la decisión de órganos terceros, el camino previsto por el art. 11 de la Carta europea de 15 de octubre de 1985 sobre autonomía local, ratificada por España mediante instrumento de 20 de enero de 1988 (BOE 47, de 24 de febrero de 1989) que establece: «Protección legal de la autonomía local. Las entidades locales deben disponer de una vía de recurso jurisdiccional a fin de asegurar el libre ejercicio de sus competencias y el respeto de los principios de autonomía local consagrados en la Constitución o en la legislación internay. La disposición de una vía de recurso jurisdiccional que asegure el libre ejercicio de sus competencias y el respeto a los principios de autonomía local consagrados en la Constitución, no se cumple en el caso de necesaria intermediación, entre la corporación local y el Tribunal dirimente, de un órgano tercero que se solidarice con la petición de garantía. Una vía de recurso que asegure el respeto a la autonomía local pasa por la posibilidad de que las corporaciones locales, sin mediatización alguna, puedan dirigirse, ser oídas y defenderse sin interposición de otro plano administrativo o político con intereses prioritarios distintos. Si este tercero puede cegar el acceso al tribunal de garantías, las entidades locales no disponen de una vía de recurso, puesto que de la vía de recurso disponen los órganos o entes interpuestos.

La Constitución, en el art. 162, b) legitima, para promover el recurso de amparo por violación de los derechos o libertades referidos en el art. 53,2 de la Constitución, a toda persona natural o jurídica que invoque un interés legítimo. Entre estos derechos y libertades protegidos por el recurso de amparo, se encuentran el derecho a la vida (art. 15), a la libertad (art. 17) y el que garantiza la tutela jurídica efectiva (art. 24). Sin entrar a indagar una posible vía de garantía de la autonomía local por los vericuetos de esos preceptos, de lo que no cabe duda, es que los derechos y libertades especiales protegidos mediante el recurso de amparo, de libérrimo acceso para toda persona, no se entenderían suficientemente protegidos si su ejercicio se subordinara a la conformidad de una cierta instancia fiscalizadora. De la misma forma, tampoco el principio de autonomía local queda asegurado si para llegar a la instancia resolutoria es preciso, necesariamente, la opinión coadyuvante de un órgano no jurisdiccional en la específica materia. Y esto es lo que ocurre con las garantías frente al legislativo o frente a las interpretaciones jurisprudenciales en punto a la autonomía local. Y la autonomía local - vida y libertad de las corporaciones locales - es previa a cualquier otro derecho fundamental o libertad pública que pueda afectarles en su condición de personas jurídicas.

Las corporaciones locales quedan así en situación de desvalimiento e inermes prácticamente en lo que concierne a la autonomía que la Constitución les garantiza. El acceso directo al Tribunal Constitucional, en defensa del principio de autonomía, carente en la actualidad de vía clara y libre, no está, sin embargo, veda- 
do por la Constitución, pues ésta admite en el párrafo 2 del art. 162, la posibilidad de legitimaciones no previstas en el párrafo 1 . No sería inconveniente reconsiderar el problema a la luz de la Carta europea sobre autonomía local, aprobada y ratificada por España con posterioridad a la ley reguladora de las Bases del régimen local.

La cuestión de las Cajas de Ahorro es un caso ejemplar de cómo se discuten, acuerdan y dirimen inapelablemente temas que conciernen principalmente a las corporaciones locales sin su intervención y cómo determinadas interpretaciones jurisprudenciales que afectan a la autonomía local, en su indispensable puntal de la suficiencia financiera, no pueden llegar de forma expedita, con el solo impulso de la corporación local afectada, al órgano encargado por la propia Constitución de velar por el principio de autonomía que proclama. En el particular asunto de las Cajas de Ahorro, las sentencias examinadas más arriba de la Sala de Revisión del Tribunal Supremo se asentaron, únicamente o como causa principal, en el allanamiento de la Administración del Estado.

Una última sentencia del Tribunal Supremo invita, una vez más, a la reflexión sobre estos temas, al reducir a las corporaciones locales al papel de espectadores inermes de sus propios destinos. Se trata de la sentencia, también reciente, de 12 de julio de 1996 (6287), que interpreta el art. 721,1 de la vieja Ley de régimen local de 24 de junio de 1955. Decía este artículo: «cuando el Estado otorgue exención de derechos y tasas y arbitrios provinciales y municipales a alguna empresa o entidad quedará subrogado en la obligación de abonar a la Corporación local respectiva el importe de los mismos con arreglo a los tipos de gravamen vigentes en la fecha del otorgamiento, salvo disposición legal en contrario. En el caso de que por el Gobierno se acuerde la desgravación, total o parcial, de arbitrios ya autorizados, municipales o provinciales, se proveerá a la pertinente sustitución por otros rendimientos y características similares». El Tribunal Supremo resuelve que no procede la subrogación o compensación solicitada por una corporación local por entender que sólo es posible en el caso de exenciones a alguna empresa o entidad, según el texto literal del precepto, no cuando la exención se concede genéricamente sin mención nominal de empresas o entidades.

No es cuestión de formular una crítica a esta intepretación, especialmente porque la nueva ley reguladora de las haciendas locales impide la utilización de este argumento, al suprimir en la redacción del equivalente art. 9,2 la expresión «alguna empresa o entidad (las leyes por las que se establezcan beneficios fiscales en materia de tributos locales determinarán las fórmulas de compensación que procedan; dichas fórmulas tendrán en cuenta las posibilidades de crecimiento futuro de los recursos de las Entidades locales procedentes de los tributos respecto de los cuales se establezcan los mencionados beneficios fisca- 
les)». Lo importante es la doctrina que el Tribunal Supremo considera sentada por sentencia anterior, de 27 de junio de 1988 (5009): «En efecto, establece dicha sentencia en su Fundamento de Derecho segundo los criterios siguientes: 1.a) El art. 721.1 de la Ley de Régimen Local impone al Estado, Administración Central, la obligación de reintegrar el importe de los tributos municipales -y provinciales - no percibidos por la Corporación Local, por motivo de exención, cuando la exención concedida por el Estado lo fuere a favor de «alguna Empresa o Entidad», es decir, con el carácter singular definido por el adjetivo determinativo «alguna», referente a "determinado» sujeto pasivo, pero no con el carácter general y amplio contenido en la disposición transitoria 3 . $^{\mathrm{a}}$ de la Ley 44 de 1978 que estableció la exención en el actual supuesto. Por lo tanto, y a ello en cierta manera también alude la sentencia de nuestra Sala Tercera de fecha 30 de abril pasado, no es aplicable la compensación..$^{2}$ ) La disposición transitoria 3. ${ }^{a}$ de la Ley 44 de 1978 no modificó la norma tributaria de los arts. 510 y 511 de la Ley de Régimen Local de 1955, ni las correspondientes de la Ley de Bases del Estatuto de Régimen Local de 1975, ni menos del Real Decreto 30 de diciembre de 1976; sino que, por la misma potestad e igual rango jurídico con que estableció el impuesto a favor de los Ayuntamientos, establece para el hecho imponible una exención por motivos relacionados con casos de disolución de sociedades; de donde, existe concordancia respecto al art. 10,b) de la Ley General Tributaria regulador de exenciones y bonificaciones tributarias acordadas por ley. Y 3. ${ }^{\mathrm{a}}$ ) La autonomía y suficiencia de las Corporaciones Locales, previstas en los arts. 140 y 142 de la Constitución, no están afectadas ni desconocidas por los fundamentos precedentes; porque la potestad originaria para establecer tributos corresponde exclusivamente al Estado, ejerciéndola siempre a tenor de las atribuciones conferidas por la Constitución y las Leyes: art. 135 de ésta y doctrina de la sentencia del Tribunal Constitucional de fecha 2 de febrero de $1981 »$.

Que la autonomía y suficiencia de las corporaciones locales quede garantizada, simplemente, porque la potestad originaria para establecer tributos corresponde exclusivamente al Estado, ejerciéndola siempre a tenor de las atribuciones conferidas por la Constitución, es una afirmación que puede despertar alarma. Porque la autonomía local obliga al legislador, que no está inmunizado contra cualquier desvarío por la sola circunstancia de cumplir en su función, con los requisitos formales. Y parece que tendría que ser el Tribunal Constitucional el que debiera tener la primera y, en todo caso, la última palabra acerca del respeto que, desde el punto de vista sustantivo, rinde el legislador al principio de autonomía local.

El último Fundamento de Derecho de la sentencia apelada, que el Tribunal Supremo confirma en la suya de 12 de julio de 1996, confiere patente al Estado para eludir por ley posterior la obligación de satisfacer compensaciones por 
REALA 271-272 (JULIO-DICIEMBRE, 1996)

exenciones concedidas de tributos locales, pese a las previsiones de las leyes reguladoras del régimen económico local. Este mecanismo de exoneración a través de ley posterior, profusamente empleado últimamente por el Estado, convierte en papel mojado, absolutamente mojado, el cuadro de suficiencia financiera y consecuente autonomía dibujado por la ley reguladora de las haciendas locales de 1988. 


\section{Sección Crónicas}

REAL-1996, núm. 271-272. DÍAZ CAPMANY, FELIPE. LAS CAJAS DE AHORRO Y LAS CORPORA... 
